\title{
First records of the megamouth shark Megachasma pelagios (Taylor, Compagno \& Struhsaker, 1983) as bycatch in Peruvian small-scale net fisheries
}

\author{
Nicolas Acuña-Perales ${ }^{1}$, Francisco Córdova-Zavaleta ${ }^{1,2}$, Joanna Alfaro-Shigueto ${ }^{1,3,4^{*}}$ and Jeffrey C. Mangel ${ }^{1,4}$
}

\begin{abstract}
Between October 2018 and October 2019, seven megamouth sharks were reported as bycatch in the small-scale surface and midwater gillnet fisheries operating from the ports of Mancora and Salaverry in northern Peru. Here we present details of these specimens and bycatch events that represent the first documented records of this species in Peruvian waters, confirming their occurrence as fisheries bycatch. We recommend continued monitoring programs in small-scale fisheries toward assessing the extent of this species' occurrence in Peru and its vulnerability to fishery interactions.
\end{abstract}

Keywords: Elasmobranchii, Lamniformes, Eastern Pacific Ocean, Northern Peru, Gillnets

\section{Introduction}

The megamouth shark, Megachasma pelagios Taylor, Compagno \& Struhsaker 1983, a large filter-feeder, was first described in 1983 based on one individual caught off Hawaii in 1976 (Taylor et al. 1983). It has a nearly global distribution in temperate and tropical waters (Compagno 2001), mainly reported from bycatch events from the Western Pacific Ocean: Taiwan, Philippines and Japan (Watanabe and Papastamatiou 2019) and occasionally from the Indian (White et al. 2004; Fernando et al. 2015) or Atlantic Ocean (Amorim et al. 2000; Rodriguez-Ferrer et al. 2017). The majority of these records derive from interactions with small-scale fisheries. A full understanding of the distribution and movements of the species is, however, still lacking (Watanabe and Papastamatiou 2019). In the southern region of the Eastern Pacific Ocean (EPO), megamouth sharks have been reported off the coast of Ecuador, with a total of 4 bycatch events between 2004 and 2016 (Romero and Liza-Santa Cruz 2004; Nakaya 2010; Martínez-Ortiz et al. 2017).

\footnotetext{
* Correspondence: jalfaros@ucientifica.edu.pe

'ProDelphinus, Calle Jose Galvez 780-e, 15074 Lima, Peru

${ }^{3}$ Facultad de Biología Marina, Universidad Científica del Sur, Antigua

Panamericana Sur Km 19, 15067 Lima, Peru

Full list of author information is available at the end of the article
}

In Peru, megamouth sharks have not yet been officially reported (IMARPE 2019b). The aim of this paper is to document the first cases of bycatch of $M$. pelagios by the small-scale gillnet fishery in northern Peru. This information highlights the vulnerability of the species to fishery interactions and contributes to our understanding of its global distribution.

\section{Methods}

The observations reported in the present study are collected as part of a long-term small-scale fisheries monitoring project operating out of multiple fishing ports along the Peruvian coast. Fishermen participating in the project are trained to collect information about target and nontarget catch species, and morphometrics. When possible, photographs are taken of catch or bycatch species to assist in species identification. However, one of the seven sharks included in this study (MP-3) was reported by a fisherman who did not take part in the monitoring program.

As part of this monitoring project, between October 2018 and October 2019, seven megamouth sharks were reported entangled in drifting surface and set mid-water gillnets by small-scale vessels operating in northern Peru. Capture dates and locations are summarized in Table 1. 


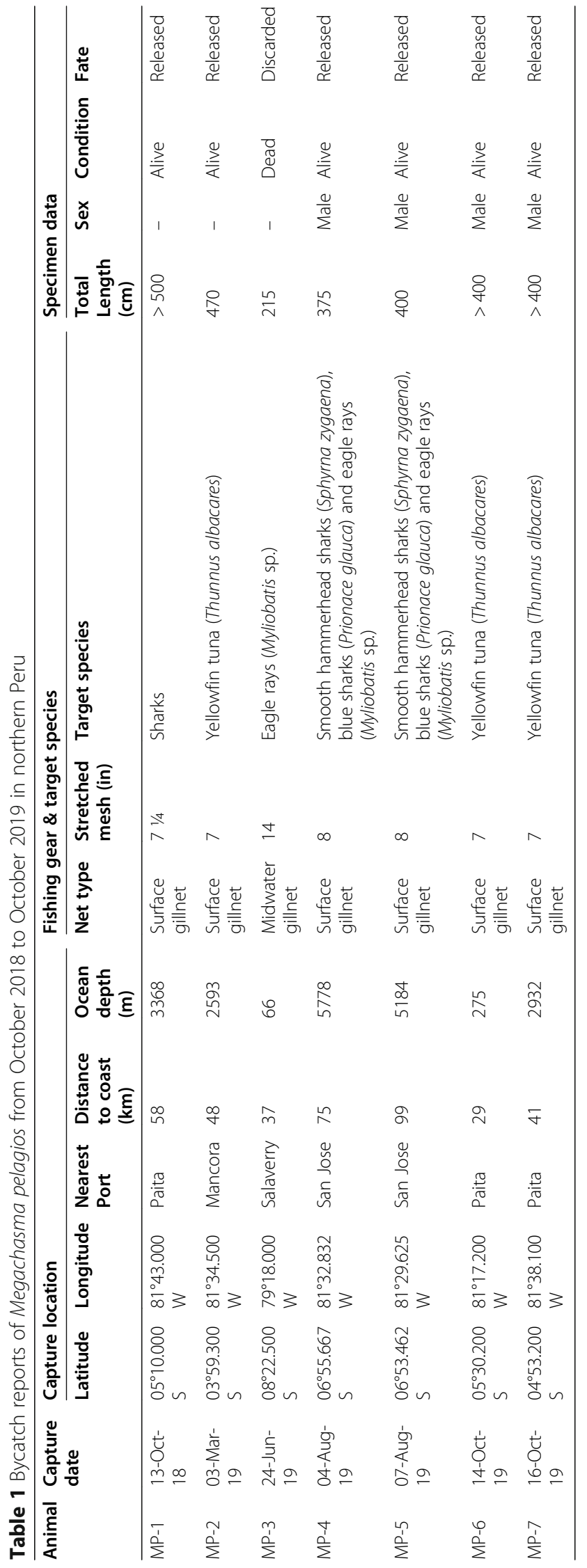


Six caught individuals were released alive after being disentangled in the water alongside the vessel, limiting the possibility of taking exact measurements. However, an average body length was estimated by comparing the size of the shark with the total length of the vessel. These measurements were verified using the mobile application FishFigure Photo, which takes as a measurement reference a selected section of the image, such as the mesh size of the nets. All reports, with the exception of MP-1, included photographic and video records to assist with species confirmation. The sex of four specimens was identified by the presence of claspers visible in photographs or videos of the interactions. Ocean depths at capture locations were extracted from the GEBCO_2014 Grid version 20,150,318 bathymetry data plotted using ESRI ArcGIS version 10.6.1. Descriptive statistics are provided as mean \pm standard deviation.

\section{Results}

A total of seven megamouth sharks bycatch events are reported in this study (Figs. 1, 2 and 3). Six individuals were alive when captured and released. Only MP-3 was found dead, entangled in fishing nets, and was brought aboard the fishing vessel to facilitate disentanglement (Fig. 1c-d). This shark was eventually discarded after the crew determined that the meat had no market value. Reported specimens occurred at a straight-line distance from the coast of $55.3 \pm 24.5 \mathrm{~km}$ (range: 29 to $99 \mathrm{~km}$, $n=7$ ) (Fig. 4) at water depths ranging from $66 \mathrm{~m}$ to $5778 \mathrm{~m}(2885 \pm 2188 \mathrm{~m}, \mathrm{n}=7)$ (Table 1). Additional data of capture locations and fishing gear and target species are given in Table 1. The estimated total length (TL) of the individuals reported in Mancora (MP-1, MP-2, MP-6 and MP-7) is $>500 \mathrm{~cm}, 470 \mathrm{~cm},>400 \mathrm{~cm}$ and $>400 \mathrm{~cm}$, respectively. Moreover, the estimated total length of the individuals reported in Salaverry (MP-3, MP-4 and MP5) were $215 \mathrm{~cm}, 375 \mathrm{~cm}$ and $400 \mathrm{~cm}$, respectively (Table 1). Four megamouth sharks (MP-4, MP-5, MP-6, MP-7) were identified as males.

\section{Discussion}

The specimens of the megamouth sharks Megachasma pelagios detailed here are the first reports of bycatch interactions of this species for Peru. Most bycatch reports for this species, including this study, have come from small-scale fisheries (Miya et al. 1992; Romero and Liza-
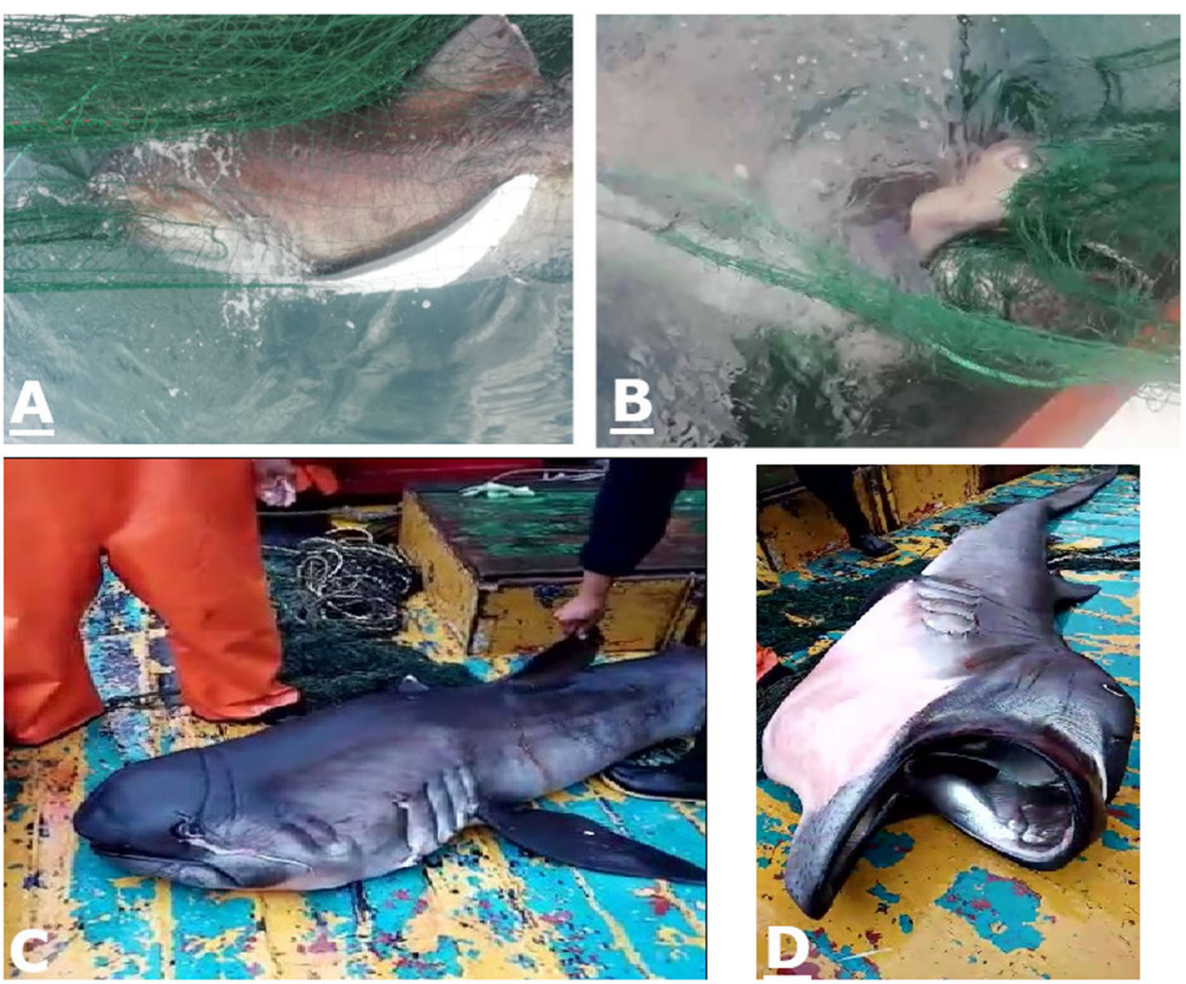

Fig. 1 Megachasma pelagios individuals from Mancora (MP-2) and Salaverry (MP-3) bycaught by small-scale net fisheries: a Lateral view of MP-2 showing the white ventral surface of a pectoral fin with the characteristic black margin, $\mathbf{b}$ anterior lateral view of the head of MP-2 with the visible white band on the upper jaw and between the nostrils. c Dorso lateral view of MP-3 showing its tadpole-like body, $\mathbf{d}$ view of the large mouth, white band on the upper jaw and white ventral hue 

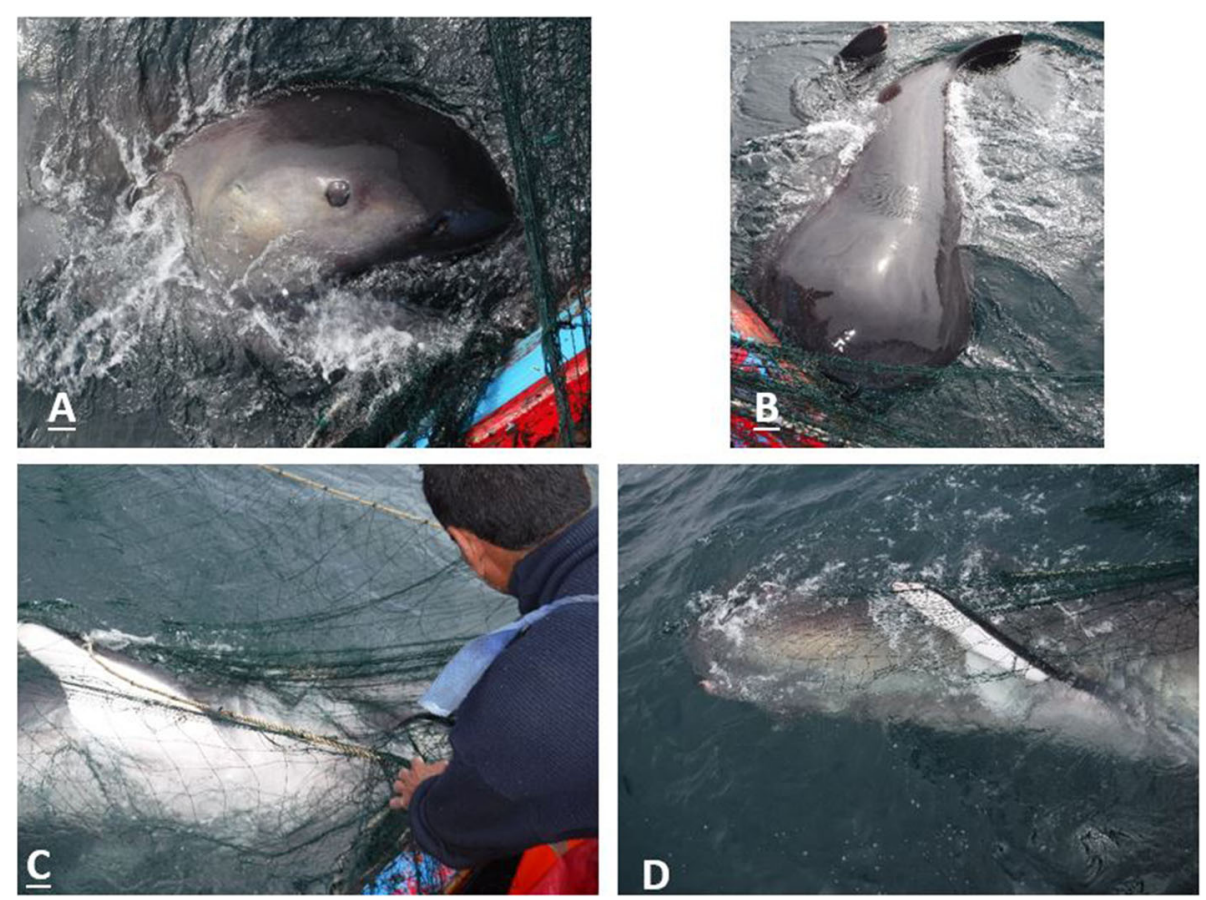

Fig. 2 Megachasma pelagios individuals (MP-4 and MP-5) from Salaverry bycaught by small-scale net fisheries: a Anterior lateral view of the head of MP-4, $\mathbf{b}$ Dorsal view of MP-4 showing its tadpole-like body (c) Ventral view of the entangled MP-5 showing the white ventral surface of its body, $\mathbf{d}$ Lateral view of MP-5 showing a pectoral fin with the characteristic black margin and nets entangled around its body
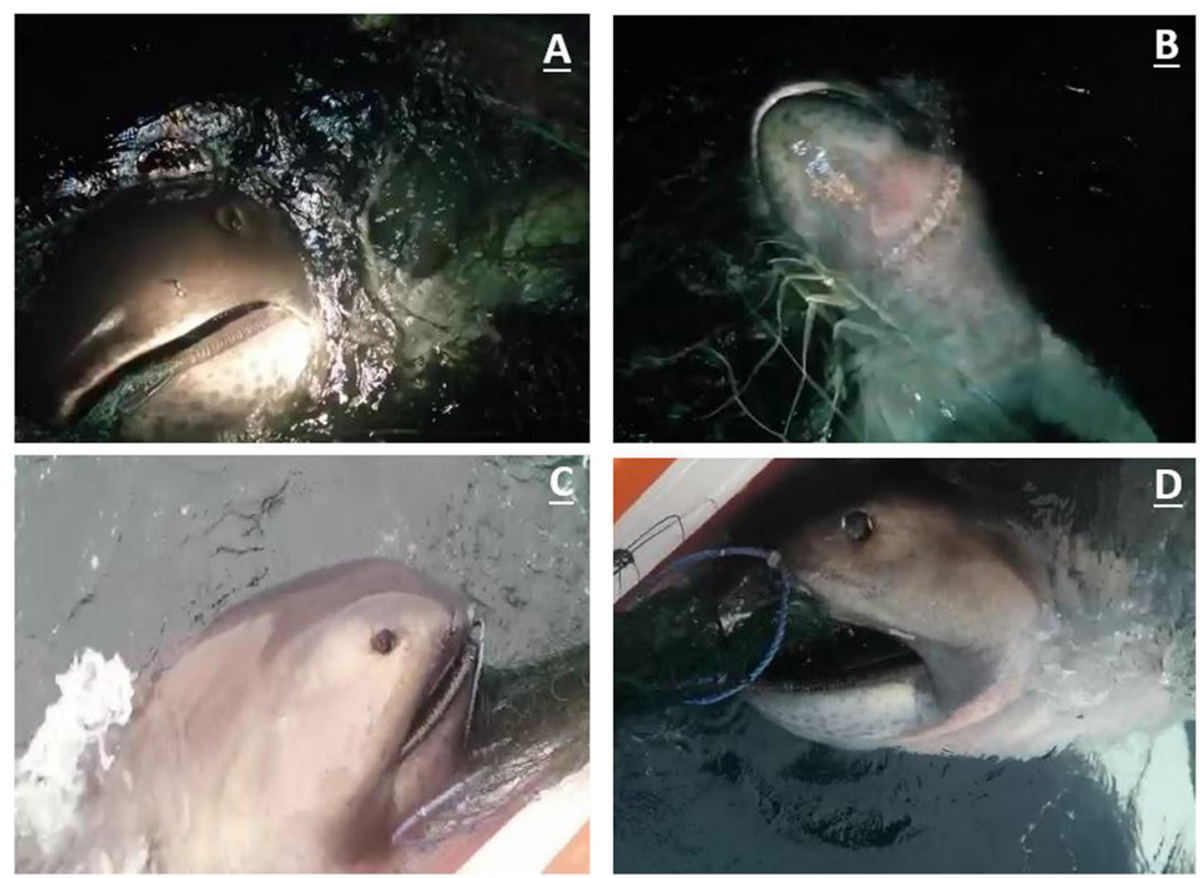

Fig. 3 Megachasma pelagios individuals (MP-6 and MP-7) from Mancora bycaught by small-scale net fisheries: a Anterior lateral view of MP-6 showing the white band on the upper jaw and with nets entangled in its mouth, $\mathbf{b}$ ventral view of MP- 6 with nets entangled by a side in its mouth. c-d Lateral views of MP-7 showing entangled nets by its mouth 


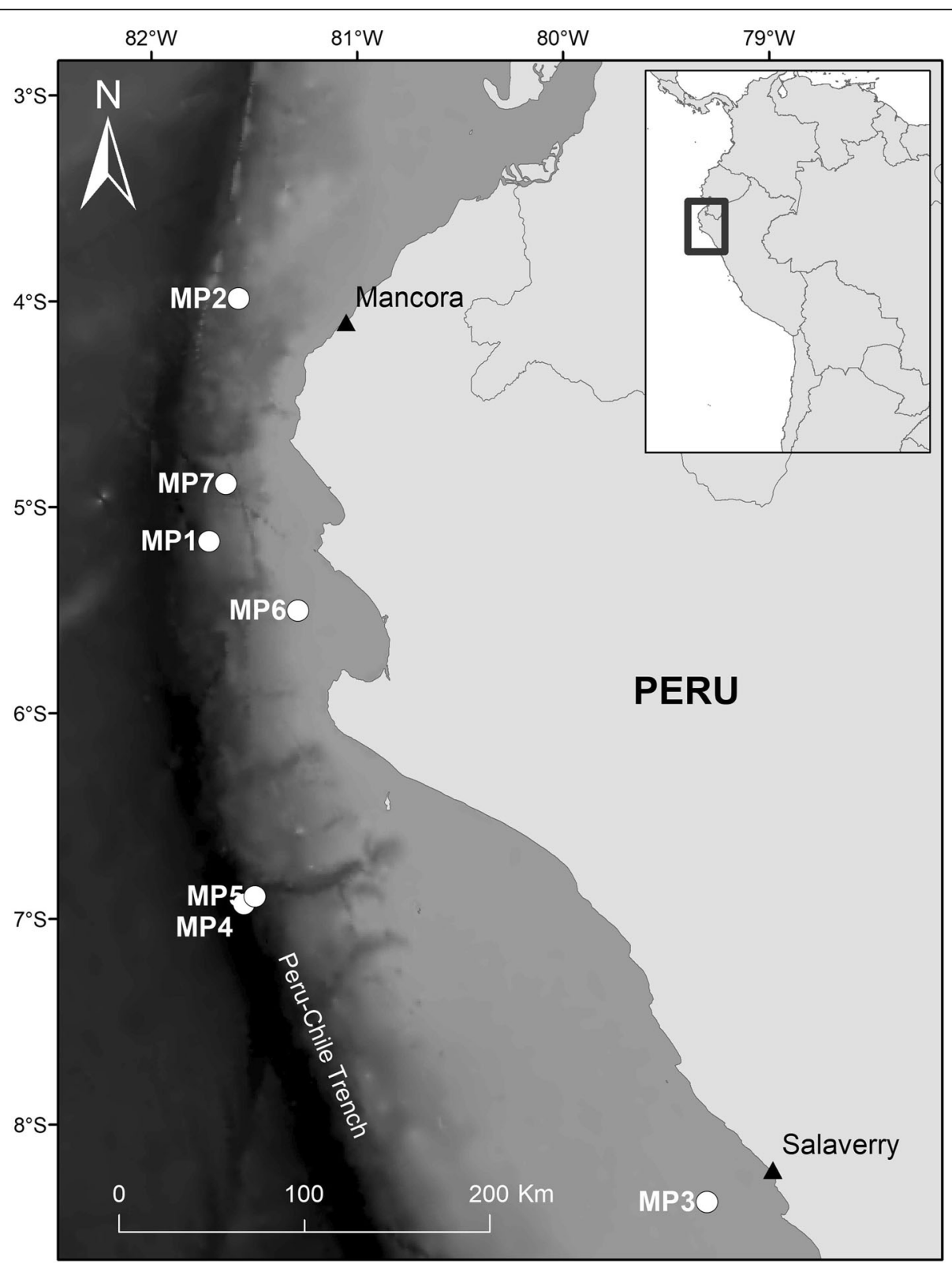

Fig. 4 Locations of bycatch of megamouth sharks (Megachasma pelagios) in northern Peru

Santa Cruz 2004; Fernando et al. 2015; Martínez-Ortiz et al. 2017). Similarly, all seven megamouth sharks reported in the present study were captured in gillnets, the gear type most reported to interact with this species (Lavenberg and Seigel 1985; Miya et al. 1992; Romero and Liza-Santa Cruz 2004; Castillo-Géniz et al. 2012; Fernando et al. 2015; Martínez-Ortiz et al. 2017).

In northern Peru, the captures occurred between the coordinates $3-9^{\circ} \mathrm{S}$, at a maximum distance of $99 \mathrm{~km}$ off the coast, which is an area where the northern region of the Peruvian Coastal Upwelling (PCU) develops (Pennington et al. 2006; Gutiérrez et al. 2014). Moreover, the
Surface Equatorial Waters (SEW), Surface Tropical Waters (STW) and Peruvian Cold Coastal Waters (PCCW) all converge and mix in this region yielding high biological primary productivity (Gutiérrez et al. 2014; Pinedo 2014). This high productivity may attract megamouth sharks to this area. A similar pattern was observed for megamouth sharks in Ecuador and Mexico (Castillo-Géniz et al. 2012; Martínez-Ortiz et al. 2017). Under these conditions, these sharks are presumably foraging in productive areas that overlap with coastal fisheries and make them prone to bycatch interactions. 
Studies have described M. pelagios as a specialized filter feeder, primarily consuming euphausiids (Taylor et al. 1983; Sawamoto and Matsumoto 2012; Liu et al. 2018; Watanabe and Papastamatiou 2019), but also copepods, jellyfish (Yano et al. 1999; Compagno 2001) and possibly small fishes, like Peruvian anchovy Engraulis ringens, reported as regurgitated food of $M$. pelagios in Ecuador (Romero and Liza-Santa Cruz 2004). The same prey groups occur in the northern region of the PCU (Gutiérrez et al. 2014; Pinedo 2014; Orosco and Ayon 2016; IMARPE 2019a; IMARPE 2019c), where the $M$. pelagios specimens are reported, which may indicate that this northern Peru zone represents a potential foraging zone for the species.

All seven reported megamouth sharks were bycaught by fisheries that use surface gillnets or relatively shallow midwater set nets which are set around dusk, soaked overnight, and collected around dawn the following day (Alfaro-Shigueto et al. 2010). Megamouth sharks seem to perform vertical migrations swimming shallow at night and up to $166 \mathrm{~m}$ during day (Nelson et al. 1997), possibly in pursuit of vertically migrating plankton. These migrations would bring them to surface waters at night when fishing nets are abundant, making them particularly vulnerable to fishery interactions. Subsequent discussions with fishermen from Mancora and Salaverry revealed that the local common name for the megamouth shark is "chirimoya shark" or "guanabana shark" ("tiburon chirimoya", "tiburon guanabana"). Mancora fishermen indicated that it is captured sporadically and in most cases released alive, suggesting that fishery interactions with megamouth sharks are not entirely uncommon in the area. On the contrary, in Salaverry, this interaction was described as unusual, and may be related to (1) abnormal environmental conditions (e.g. shifting currents or temperatures, or variations in food availability) or (2) a poor awareness of the species by fishermen (e.g. not being able to identify the species, not reporting bycatch events). In addition, because they are large-sized animals (Compagno 2001), the majority of $M$. pelagios are disentangled and released while in the water, making it more difficult to document their bycatch. This is the first time such a high number of bycatch events' of megamouth sharks has been reported in such a relatively small area over a short time period. This proves the need for an extended and systematic study in similar ports along the Peruvian coastline. This would (1) improve our knowledge of the species presence and distribution within the PCU and (2) demonstrate the danger that fisheries present to the vulnerable megamouth sharks.

\section{Abbreviations}

EPO: Eastern Pacific Ocean; IMARPE: Instituto del Mar del Perú: IUCN: International Union for Conservation of Nature; NGO: Non-
Governmental Organization; PCU: Peruvian Coastal Upwelling; TL: Total Length

\section{Acknowledgements}

We would like to thank fishermen from Mancora and Salaverry who are part of the small-scale fisheries monitoring project. We also thank ProDelphinus staff for helping on data collection and Mr. Vela for support during our fieldwork.

\section{Authors' contributions}

NAP collected the data from fishermen. All authors made the identification of the species. NAP analyzed and redacted the manuscript. FCZ, JAS and JCM edited the manuscript. All authors read and approved the final manuscript.

\section{Funding}

Data collection partially occurred during a project funded by el Subproyecto del Programa Nacional de Pesca e Innovación en Pesca y Acuicultura PESSIADE-PP 000016.

\section{Availability of data and materials}

No database was used and/or analyzed for this study.

Ethics approval and consent to participate

Not applicable.

Consent for publication

Not applicable.

\section{Competing interests}

The authors declare that they have no competing interests.

\section{Author details \\ ${ }^{1}$ ProDelphinus, Calle Jose Galvez 780-e, 15074 Lima, Peru. ${ }^{2}$ Centro Interdisciplinario de Ciencias Marina, Instituto Politécnico Nacional Avenida Instituto Politécnico Nacional s/n, La Paz, Baja California Sur, Mexico. ${ }^{3}$ Facultad de Biología Marina, Universidad Científica del Sur, Antigua Panamericana Sur Km 19, 15067 Lima, Peru. ${ }^{4}$ Centre for Ecology and Conservation, College of Life and Environmental Sciences, University of Exeter, Penryn Campus, Penryn, Cornwall TR10 9FE, UK.}

Received: 23 August 2019 Accepted: 18 December 2020 Published online: 05 January 2021

\section{References}

Alfaro-Shigueto J, Mangel JC, Pajuelo M, Dutton PH, Seminoff JA, Godley BJ. Where small can have a large impact: structure and characterization of smallscale fisheries in Peru. Fish Res. 2010;106:8-17.

Amorim AF, Arfelli CA, Castro Jl. Description of a juvenile megamouth shark, Megachasma pelagios, caught off Brazil. Environ Biol Fish. 2000;59:117-23.

Castillo-Géniz JL, Ocampo-Torres Al, Shimada K, Rigsby CK, Nicholas AC. Juvenile megamouth shark, Megachasma pelagios, caught off the Pacific coast of Mexico, and its significance to chondrichthyan diversity in Mexico. Ciencias Mar. 2012;38(2):467-74.

Compagno LJV. Sharks of the world. An annotated and illustrated catalogue of shark species known to date. Volume 2. Bullhead, mackerel and carpet sharks (Heterodontiformes, Lamniformes and Orectolobiformes). FAO Species Cat Fish Purp. 2001;2(1):269

Fernando D, Perera N, Ebert DA. First record of the megamouth shark, Megachasma pelagios, (Chondrichthyes: Lamniformes: Megachasmidae) from Sri Lanka, northern Indian Ocean. Mar Biodivers Rec. 2015;8:1-3.

Gutiérrez D, Grados C, Graco M, Vásquez L, Velazco F, Sánchez S, et al. El mar peruano y su dinamica. 50 años mar y Cienc; 2014. p. 34-59.

IMARPE. Informe de las Condiciones Oceanográficas y Biológico Pesqueras Mayo 2019. 2019a.

IMARPE. Solicitud de Acceso a la Información Pública: Reportes del "tiburón boquiancho" Megachasma pelagios en el Perú, entre los años 1990 y 2018. (Carta N 168-2019-IMARPE/OGA). Callao: IMARPE; 2019b.

IMARPE. Situación del Stock Norte-Centro de la Anchoveta Peruana (Engraulis ringens) al 05 de Noviembre de 2019 y Perspectivas de Explotación Para la Segunda Temporada de Pesca 2019; 2019c. p. 25. 
Lavenberg RJ, Seigel JA. The Pacific's megamystery- Megamouth. Terra. 1985; 23(4):30-1.

Liu SW, Joung SJ, Yu CJ, Hsu HH, Tsai WP, Liu KM. Genetic diversity and connectivity of the megamouth shark (Megachasma pelagios). PeerJ. 2018:1-14.

Martínez-Ortiz J, Mendoza-Intriago D, Tigrero-Gonzalez W, Flores-Rivera G, LópezParraga R. New records of megamouth shark, Megachasma pelagios off Ecuador, Eastern Pacific Ocean. Cienc Pesq. 2017;25(2):27-30.

Miya M, Hirosawa M, Mochizuki K. Occurrence of a megachasmid shark in Suruga Bay: photographic evidence. J Nat Hist. 1992;2(1):41-4 Available from: http:// www.researchgate.net/publication/233922712_Occurrence_of_a_ megachasmid_shark_in_Suruga_Bay_photographic_evidence. Museum Institute, Chiba.

Nakaya K. Biology of the Megamouth Shark, Megachasma pelagios (Lamniformes: Megachasmidae). Proc. Int. Symp. Unknown, Res. Myster. Deep. Anim. Okinawa: Okinawa Churaumi Aquarium; 2010. p. 69-83.

Nelson DR, McKibben JN, Strong WRJ, Lowe CG, Sisneros JA, Schroeder DM, et al. An acoustic tracking of a megamouth shark, Megachasma pelagios: a crepuscular vertical migrator. Environ Biol Fish. 1997;49:389-99.

Orosco X, Ayón P. Abundancia, Frecuencia Y Distribución De Eufausidos Frente a La Costa Norte Del Perú. Rev. Ciencias. 2016;11:20-30.

Pennington JT, Mahoney KL, Kuwahara VS, Kolber DD, Calienes R, Chavez FP. Primary production in the eastern tropical Pacific: a review. Prog Oceanogr. 2006;69(2-4):285-317.

Pinedo E. Estructura comunitaria del zooplancton de la costa peruana asociado a las masas de agua durante los veranos del 2000 y 2003; 2014.

Rodriquez-Ferrer G, Wetherbee BM, Schärer M, Lilyestrom C, Zegarra JP, Shivji M. First record of the megamouth shark, Megachasma pelagios, (family Megachasmidae) in the tropical western North Atlantic Ocean. Mar Biodivers Rec. 2017;10(1):1-4.

Romero M, Liza-Santa Cruz J. Megamouth Caught for First Time in the Pacific Ocean off the Coast of South America. Florida Museum Nat Hist. 2004; Available from: https://www.floridamuseum.ufl.edu/discover-fish/sharks/ megamouths/ [cited 2019 Jun 20].

Sawamoto S, Matsumoto R. Stomach contents of a Megamouth shark Megachasma Pelagios from the Kuroshio extension:evidence for feeding on a Euphausiid swarm. Plankt Benthos Res. 2012;7(4):203-6.

Taylor LR, Compagno LJV, Struhsaker PJ. Megamouth-a new species, genus, and family of Lamnoid shark (Megachasma Pelagios), family (Megachasmidae) from the Hawaiian islands. Proc Calif Acad Sci. 1983:43(8):87-110.

Watanabe YY, Papastamatiou YP. Distribution, body size and biology of the megamouth shark Megachasma pelagios. J Fish Biol. 2019:1-7.

White WT, Fahmi MA, Sumadhiharga K. A juvenile megamouth shark Megachasma pelagios (Lamniformes: Megachasmidae) from northern Sumatra, Indonesia. Raffles Bull Zool. 2004;52(2):603-7.

Yano K, Yabumoto Y, Tanaka S, Tsukada O, Furuta M. Capture of a mature female Megamouth Shark, Megachasma pelagios, from Mie, Japan. Proc. 5th IndoPacific Fish Conf; 1999. p. 335-49.

\section{Publisher's Note}

Springer Nature remains neutral with regard to jurisdictional claims in published maps and institutional affiliations.

Ready to submit your research? Choose BMC and benefit from:

- fast, convenient online submission

- thorough peer review by experienced researchers in your field

- rapid publication on acceptance

- support for research data, including large and complex data types

- gold Open Access which fosters wider collaboration and increased citations

- maximum visibility for your research: over $100 \mathrm{M}$ website views per year

At BMC, research is always in progress.

Learn more biomedcentral.com/submissions 